\title{
A PROCEDURAL AND EFFECTIVE LANGUAGE TEACHING-LEARNING THROUGH PPP TECHNIQUE
}

\author{
I Komang Budiarta \\ Mahasaraswati Denpasar University \\ mrbudi@unmas.ac.id
}

\begin{abstract}
English is an international language that should be mastered if we want to communicate with people around the world. Unfortunately in Indonesia, English becomes a frightening lesson. This condition might happen because the inability of the lecturers in choosing and varying teaching technique. This hence encourages the writer to try to offer a procedural and effective teaching technique to support learning the language, that is, PPP (Presentation Practice and Production). Each phase of this technique is well organized as it has different things to be applied so that the students will find the technique much more various and interesting. During the three phases, both lecturer and students will do different activities, for example, participation or lecturers' roles and students' roles, types of control, and mistakes' treatment. The only thing that makes this technique is quite different with other techniques is that it provides the students with a plenty of times to practice what they have already studied in the classroom. Therefore, the students will learn the language contextually by using a procedural and effective teaching technique.
\end{abstract}

Keywords: procedural, effective, language teaching and PPP technique.

\begin{abstract}
ABSTRAK
Bahasa Inggris merupakan bahasa internasional yang harus dikuasai jika kita ingin berkomunikasi dengan orang-orang di seluruh dunia. Akan tetapi Bahasa Inggris di Indonesia menjadi salah satu 'momok' pelajaran yang paling tidak disenangi. Hal ini merupakan implikasi dari kurangnya pengetahuan guru dalam memilih dan memvariasikan teknik mengajar yang cocok dan sesuai diterapkan di kelas. Hal inilah yang mendorong penulis untuk mencoba menawarkan sebuah teknik mengajar yang kronologis dan untuk efektif mendukung pembelajaran bahasa yaitu PPP (Presentation, Practice dan Production). Setiap tahapan diatur dengan baik dan terdapat hal-hal berbeda yang diterapkan sehingga teknik ini menjadi lebih variatif dan menarik. Di setiap tahapan, baik guru maupun siswa melakukan kegiatan yang berbeda seperti partisipasi atau tugas guru dan siswa, jenis pengontrolan yang dilakukan oleh guru, dan perlakuan yang diberikan terhadap kesalahan-kesalahan siswa. Hal yang membuat teknik ini berbeda adalah kesempatan yang diberikan kepada siswa untuk mempraktekkan materi yang sudah didapat. Oleh karena itu, siswa akan menemukan essensi belajar dalam sebuah konteks pembelajaran yang tepat melalui teknik mengajar yang efektif dan sistematis.
\end{abstract}

Kata kunci: prosedural, efektif, pembelajaran bahasa, dan teknik PPP. 


\section{INTRODUCTION}

In Indonesia, English is the first foreign language which is formally taught as a compulsory subject from elementary to university. Even nowadays, English is taught at pre-elementary school. Hence in order to create enjoyable and meaningful teaching learning process, English lecturers should be creative and adaptable. In addition, English lecturers should always evaluate themselves and the ability of implementing appropriate teaching techniques becomes important.

The discussion of teaching technique, however, is rarely published or discussed. Consequently, the output of the teaching learning process is poor because of poor ability of the lecturers in choosing and implementing appropriate teaching technique. To gain communicative performance that is the ability to communicate in spoken or written forms, lecturers should be able to choose and implement suitable teaching technique so that teaching learning process can be effectively carried out. Therefore, the implementation of suitable teaching technique in an appropriate learning context will produce significant result.

The commonly used teaching techniques tend to emphasize on passive skills, listening and reading. In addition, the techniques also overaccentuate the use of English components, for example, grammatical features. This kind of teaching learning process, of course, will produce passive language users who master the language components; they however do not know how to use the language in a real communication context of spoken and written form.

In teaching learning process of English, there are so many readyto-use teaching techniques that might be applied. One of these techniques is PPP which stands for Presentation, Practice and Production. This technique is adaptable and it can be used to teach not only English language components but also English language skills both passive (i.e. listening and reading) and active skills (i.e. speaking and writing). 
Furthermore, Richards and Renandya (2002:93-94) state that PPP involves presentation of a new language item, practice of the item under controlled conditions, and a production phase in which the learners try out the form in a more communicative context. The technique has a clearly cut procedure that makes the teaching learning process run procedurally.

As the discussion of the teaching technique especially PPP technique is very broad, in the present discussion, the writer focuses the procedure of the implementation on PPP technique procedurally and evaluating the advantages of implementing PPP technique in teaching language components.

In this paper, the writer employed three writing methods that are expected to be able to support this work such as: observation, the writer observed the improvement of the second semester of Biology English Education Study Program students in which PPP was used during the pre-, whilst- and postteaching learning process; interview, the writer interviewed the students in general after teaching learning process; and review of related literatures, the writer reviewed some literatures that are related with the paper.

\section{Concept of Approach, Method, and Teaching Technique}

According to some English teaching books, the terminologies of approach, method, and teaching technique are clearly divided. Hubbard et al. (1987:123), for example, state that Approach is basic theory that is used in studying English; Method is the combination of teaching techniques; and Teaching Technique is defined as teaching procedure that is applied in classroom teaching.

In addition, anonymous in the book entitled Teaching Learning Strategy, writes that Approach is basic theory of how to learn English naturally; Method is the combination of teaching techniques, and it tends to explain or describe the roles of the lecturers and students in teaching learning process and Teaching Technique is practices or activities that are employed in the class.

To sum up, Approach is basic theory that contains how to teach and 
learns English, for example, behaviorist, structural, contextual approach, etc. Method is combination of teaching techniques in which the roles of the lecturers and students are clearly described, for example, grammar translation, direct, audio-lingual, etc. Teaching Technique is the way or procedure that is used in the class to accomplish the learning objectives, for example, TPR Technique (Total Physical Response); and PPP Technique (Presentation, Practice, and Production).

\section{PPP Technique}

PPP Technique is teaching technique that is based on Grammar Translation Method and Audiolingual Method. Hubbard et al. (1987:23) state that grammar translation method is the oldest teaching method in which it emphasizes on teaching structural items and lexical items and the expected outcome of this method is to enable students to be able to write and read well. On the other hand, Baker and Westrup (2000:78) argue that this method has weakness that it cannot be utilized in teaching spoken language or functional expressions.

PPP technique as a teaching technique is also drawn from Audiolingual Method. Baker and Westrup (2000:78) utter this method is contradictory method with grammar translation method because it emphasizes on improving the students' ability in listening and speaking. Baker and Westrup (2000:79) declare Audio-lingual Method is based on the thought that it is better to learn English as if they study their mother tongue. In other words, this method highlights on the role of lecturer who only manage the learning material brought by the students.

According to Baker and Westrup (2000:24), Pollard (2008:22), Richards (2003:8), and Harmer (2001:82) PPP stands for Presentation, Practice, and Production; in other words, it has three stages in language teaching. The three steps, presentation, practice and production, can be described as follows. 
Presentation, in this step, lecturer presents the material as creative and interesting as possible to attract the students' attention. This step is the staring point that is intended to direct or focus the students' attention to the materials which are going to be discussed. It can be done through brainstorming or asking some questions that relate and direct the students to the learning material to be taught so that the students are ready to continue to the next phase.

Practice, this stage is the segment where reinforcement is conducted by giving the students practices. When the lecturer gives the students practices, lecturer should correct the students' mistake without humiliating them and guide them to study English correctly.

Production is last stage of the PPP technique in which the students are given a chance to practice or use the material taught. In other words, the students should be more active while the lecturer just pay attention to them during they do the practices and note the students' mistakes so that it could be generally corrected at the end of the practices.

\section{DISCUSSION}

The Procedural Implementation of PPP Technique

PPP technique consists of three stages such as Presentation, Practice and Production. The following are succinct and concise descriptions of each stages PPP technique that can be used in teaching English.

\section{Presentation}

Harmer (2007:64) states that in presentation sessions the lecturer presents the context and the situation for the language and both demonstrate in the form of the new language. The lecturer explains about the language that will be taught for the students. In addition, in this procedure the lecturer introduces a situation which contextualized the language to be taught. Baker and Westrup (2000:24) add that during the presentation the lecturer introduces the new language items that the students need to learn. During the presentation, the lecturer does most of talking and has strong 
control over the students. The lecturer tells the students about the materials and demonstrates new language by showing pictures or real objects. Pollard (2008:22) adds that presentation involves as the name suggests presenting a language point which is usually done by the lecturer.

The activities that are usually done in the first stage of PPP technique, presentation are as follows:

1. Lecturer presents the material by giving some examples or modeling language, makes sure that the students understand, for example, meaning, usage, spelling and pronunciation. Since presentation is the first stage in teaching learning process, this stage is very important to direct or focus the students' attention to the material to be taught. Thus, the material should be presented as creative and interesting as possible. It can be carried out by using objects or realia or drawing the objects or writing them; giving the situation where they are used or their contextual use; playing cassettes, CDs, VCDs or
DVDs related to the material and modeling or using gestures that help the students to guess about the material. Instead of the above objects that are used in teaching or presenting the material, the following activities are also necessitated to make the presentation phase more interesting: choosing one of the aforementioned teaching objects, giving or modeling the material by saying or emphasizing it twice or three times, asking the students to repeat the material together, in group, row, and in pairs, writing on the board or displaying the material and checking the spelling and the pronunciation, explaining about the structural features used if it is needed, asking the students to take note since the more the senses involved, the better the memory.

2. Students pay attention and try to understand the material taught also ask questions if they find difficulties.

3. Lecturer controls the students and takes most of the talking time portion. 
4. Lecturer fixes every student's mistake straight away after they give response, of course, without humiliating them but motivating them to study.

\section{Practice}

Baker and Westrup (2000:23) explain that in this phase, the students need to have plenty of activities to help them to practice the new language. It is very important that students have enough practice of the new language. Pollard (2008:22) states that practice in this phase refers to control practice which involves students using the target language in a controlled way. This might involve drills, controlled written and speaking activities. Harmer (2007:65) states that practice is very important to practice what the students have learned. In practicing stage, the lecturer puts the students in pair to practice the sentences. This is for checking that the learning has been affective. Practice must not begin until the lecturer is sure that the students understand the language they are using

It should be noted that lecturer can continue to this stage if he/she feels that students have already been directed or focused, so they have understood the material taught. Besides, they are ready to go on with the next step. The following are some activities that can be implemented during the practice stage:

1. Lecturer gives practices. The process of giving practices is suggested to start from the simplest one where the lecturer manage and control everything in that practice while the students only do the practices (controlled practice). Next lecturer may give them less controlled practice in which lecturer only initiates or direct the students in doing practice related to the material (Free Practice).

2. The students perform and follow the activities in practices stage attentively.

3. Lecturer starts to loosen the control especially when they carry out the practices in order to give them enough space to practice the material taught. 
4. Lecturer corrects the students' mistakes and guides the usage correctly.

\section{Production}

According to Pollard (2008:22), production refers to the freer practice students use the target language in sentences their own. These activities are motivating and interesting. In addition, Baker and Westrup (2000:23) state that in production phase the students need time to use the new language that they have learned in communication. Therefore, the new language becomes part of students' own language and the students would be able to use it easily. Harmer (2007:66) adds that this stage is important because the students should be encouraged to use the language that the students have already learned in previous lesson. They moreover will have a plenty of times to produce the new language by their own.

In this stage, the students try to perform the material contextually, which has been taught. It is suggested that when lecturer gives the chance to perform the material, it should be put in its contextual use so that students will know when and how to use it in everyday life.

During the production stage, especially when the students perform the material, it is recommended not to cut and correct the students' mistake. Lecturer, however, lets them and corrects them at the end of their performance (general correction), or lecturer allows the other students to do correction. Some of these activities can be applied in production stage:

1. Lecturer gives the students chance to use or perform the material that has been taught so that the students will understand the material contextually.

2. Students use and practice or perform English base on the material which they have learned.

3. Lecturer does silent control that is a control which is silently conducted by the lecturer to avoid embarrassment of being corrected.

4. Lecturer notes every mistake made by students; however, it is better not to correct them straight away, and it can be done at the end of the performance (general 
Correction). In some cases, it really affects the students' psychological state since they are highly motivated to learn English instead of being humiliated while correcting them.

Baker and Westrup (2000) clarifies that there are four activities emphasized in implementing PPP technique in language teaching. These four activities are lecturer's roles, students' participation, lecturer's control and mistakes' treatment. They can be briefly explained as follows:

\section{Lecturer's Roles}

This feature emphasizes on the main task or roles that should be carried out by the lecturer in each stage (active - passive - passive).

\section{Students' Participation}

In this feature, it emphasizes on the activities that should be followed by the students in each stage (passive - active - active).

\section{Lecturer's Control}

In general, there three types of control which can be conducted by lecturer during the implementation of PPP technique:
- Firm Control, this type of control is usually done during the presentation stage. Lecturer strictly directs or focuses the students' attention to the material which is going to be explained. In other words, most of the talking time portion is taken by lecturer's talking time. Sometimes this type of control not only uses in presentation but also during practice especially when the lecturer wants to give drilling.

- Less Firm Control, less firm control is commonly applied during practices. In this stage, lecturer gives the students freedom while doing practices.

- Silent Control, the last type of control is frequently conducted when teaching learning process is on production stage. Lecturer's control is done non verbally, and lecturer only observes the students and notes their mistakes without 
correcting them directly to avoid embarrassing them.

\section{Mistake's treatment}

The treatments of mistakes done in this stage are different in each stage. They are varied as follows. In presentation, lecturer corrects every mistake made by the students directly after they answer or response the questions. Lecturer, of course, does not have to correct them strictly since in this phase they 'are introduced' with the new material. Therefore, do it as soft and gentle as possible to show that the material is not difficult and also to avoid embarrassment. In practice, lecturer still corrects the mistakes directly as in the first stage; in addition, lecturer should keep guiding them to use or learn the material correctly. And in production, lecturer only notes mistakes made by the students when they are given a chance to practice or perform the material that has been taught. Lecturer does not correct the students' mistakes in a straight line, but it is suggested after they have completed performing their chance. Moreover, the correction is done in general without pointing out one student in order to avoid a feeling of being humiliated.

In teaching learning process especially elementary school, lecturer should not ignore the importance of reinforcement or the act of giving compliment or appreciation to the students. Giving reinforcement to students is very important and can be used as an alternative way to raise the their motivation in learning English and it can be utilized to build emotional communication with the students.

In accordance with the way of giving the reinforcement, reinforcement can be classified into two categories. The first is verbal reinforcement is done through words, phrases or sentences, for example, Good!, Very Good!, Excellent!, Good job!, I like that!, etc. In addition, non - verbal reinforcement is non - verbally done by using our body language such as mimicry, gesture, or enjoyable activities, for 
example, smiling, nodding our head, giving our thumb, etc.

On the other hands, in line with the intention of giving the reinforcement, it can be grouped into two. They are reward (positive reinforcement) and punishment (negative reinforcement). In the writer's opinion based on his experience as lecturer in elementary and also students, most of the students tend to be more motivated if the lecturer gives the reward rather than punishment that will make them unmotivated. Lecturer who teaches in elementary school, consequently, is suggested to implement use positive reinforcement or reward because it will make them highly motivated in teaching learning process. Furthermore, the reinforcement given should not be monotonous, it should be varied, for example, don't use verbal reinforcement or vice versa.

Before finishing the lesson, it is better for the lecturer to summarize or conclude the material or give two or three post test questions to know the degree of their understanding concerning the material given. It also can be used by the lecturer to know the effectiveness of their teaching technique so that they will be able to analyze and revise the weakness of the applied technique. As a result, the teaching technique that has been implemented will be much better.

If all of the above steps are procedurally conducted by the lecturer and some adaptations, the writer believes that teaching learning process will be much more enjoyable and meaningful. In addition, since the process is qualified, the out put will be automatically qualified and produce qualified human resources.

\section{The Significance of PPP Technique}

Baker and Westrup (2000), Pollard (2008), and Harmer (2001) mention that a lot of significances can be gained by implementing PPP technique in teaching English components. This technique enables the students to use or perform the material that has been learned. Furthermore, this phase used to be ignored by some English lecturers that make the students only master or understand the material without 
being able to use it in daily life or its context.

The following are some advantages of implementing PPP technique in teaching English components:

- It can be used by lecturers' candidate or new lecturer as guidance in teaching English components.

- It will help the lecturer in presenting the material as simply as possible.

- It will attract the students' attention and also avoid them from being bored.

- It can be used to balance lecturer talking time and the students' activities.

- It will give the students enough time to practice and to perform the material taught so that they will be able to use the language accurately and fluently.

- It can be utilized to elicit or to motivate the students to be more active in teaching learning process.

- It can be used to assist the in improving their skills in English (i.e. listening, reading, speaking, and writing).

- This technique is flexible and adaptable, and it can be used in different level of the students.

Considering the importance of PPP technique, this technique is worth to be implemented in teaching learning process. Furthermore, teaching learning process can be chronologically conducted, and the lecturer will be much easier in following every step in this technique. It also provides lecturer with his/her roles and the students' roles. However, lecturer should be able to adapt the technique in line with the students' level, and lecturer should be able to prepare the material as interesting as possible. Finally, the students will understand the material.

\section{CONCLUSION}

Based on the discussion of this paper, "A Procedural and Effective Language Learning Through PPP Teaching Technique”, the writer concludes the following things:

- PPP technique should be procedurally implemented in 
order to get effective and significant result of language learning. They should be carried out based on its phases (Presentation, Practice and Production).

- PPP technique brings benefit both for the lecturer and students. For the lecturers, they have a procedural teaching learning process which is important to maintain the students' focus and the students will enjoy learning in step by step rising learning process.

This result can be further used as the following.

- The English lecturers especially they who teach English skills or components is suggested to implement PPP in teaching learning process.

- The students are suggested to pay attention to the material taught so that it can be easily understood.

\section{REFERENCES}

Anonymous, Teaching Learning Strategy.

Baker, J. and Westrup, H. 2000. The English Language Teacher's Handbook: How to Teach large Classes with few Resources. Great Britain: VSO.

Harmer, J. 2001. The Practice of English Language Teaching (Third Edition). Great Britain: Longman Group Ltd.

Harmer, J. 2007. The Practice of English Language Teaching (Fourth Edition). England: Pearson Education Limited.

Hubbard, J., Jones, H., Thorton, B. and Wheeter, R. 1987. A Training Course for TEFL. Hongkong: Oxford University Press.

Pollard, L. 2008. Teaching English. Available on www.farsupervision.files. wordpress.com.

Richards, J. C. 2003. Second Language Writing. New York: Cambridge University Press.

Richards, J. C. and Renandya, W. A. 2002. Methodology in Language Teaching: An Anthology of Current Practice. New York: Cambridge University Press. 